\title{
Underemployment in Urban and Rural America, 2005-2012
}

\author{
JUSTIN R. YOUNG
}

$\mathrm{T}$ The effects of the Great Recession, which began in December 2007 and officially ended in June 2009, ${ }^{1}$ continue to ripple through the U.S. economy. In September, unemployment fell below 8 percent for the first time in nearly four years, though the total number of persons "marginally" attached changed little in the past year. ${ }^{2}$ Like unemployment, underemployment-a measure defined here to include part-time workers in search of full-time work or working part-time because the hours of a former full-time job were reduced involuntarily-is also stubbornly high. In 2009, nearly 9 million Americans were working part-time but seeking full-time employment (sometimes referred to as "involuntary part-time workers")-more than twice as many from the year prior. ${ }^{3}$ These workers represent a source of untapped economic capital, as their jobs do not allow them to maximize their output or skills. This has consequences for both the economy as a whole and the well-being of the underemployed and their families.

This brief uses data from the Current Population Survey (CPS) to examine changes in underemployment since 2005 among rural and urban workers. The terms "underemployment" and "involuntary part-time employment" are used interchangeably throughout. Except in Table 1, the analysis excludes those not in the labor force or whose labor force status is listed as "unemployed"; this allows us to gauge exclusively what percentage of the working population is experiencing involuntary part-time work. This is consistent with past research examining underemployment. ${ }^{4}$

\section{Underemployment Is Less Common Than Unemployment}

In 2012, roughly 6 percent of the U.S. labor force was underemployed, and an additional 8 percent were unemployed (Table 1). In all, slightly less than 14 percent of the labor force was either underemployed or unemployed.

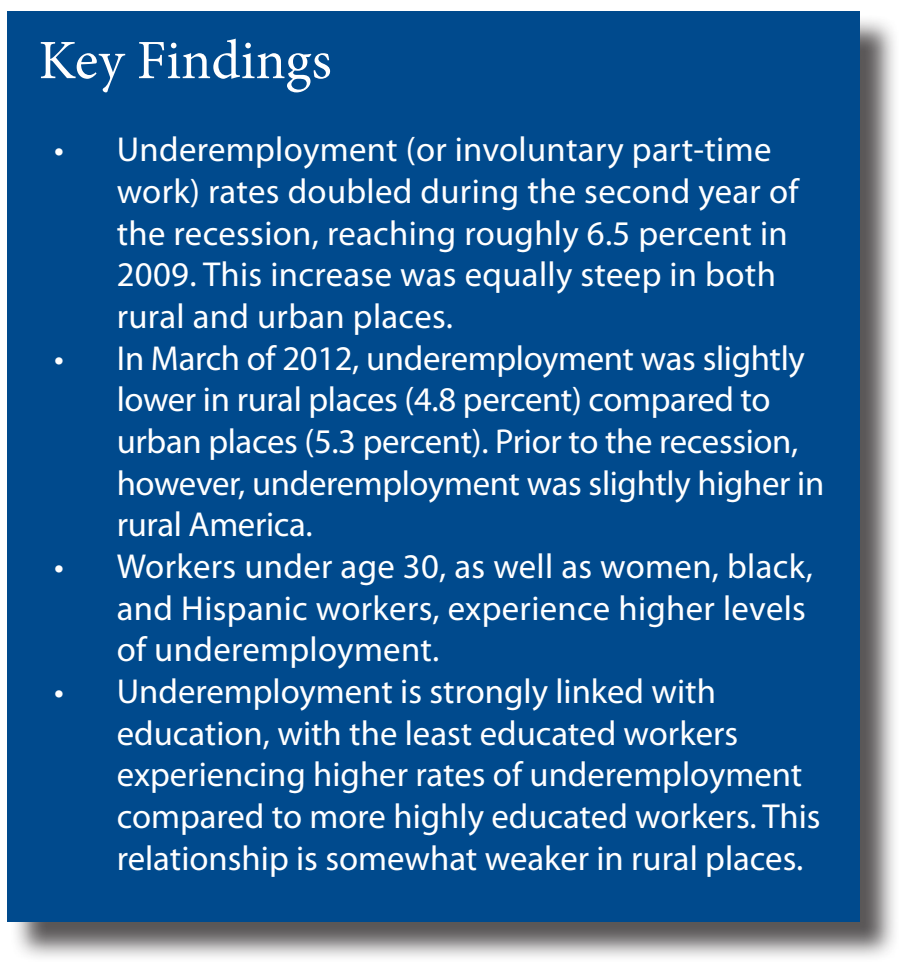

Underemployment was particularly high among workers under age 30. Indeed, adding underemployment paints an even grimmer outlook for the youngest workers, particularly those aged $18-21$. Just less than 30 percent of workers in this age group were either underemployed (10 percent) or unemployed (19 percent) in 2012. ${ }^{5}$ Nonwhites also suffered higher than average underemployment and unemployment, with one-fifth of blacks and Hispanics in those situations. These rates are higher still among young nonwhites; 43 percent of blacks and 32 percent of Hispanics aged 18-21 were either underemployed or unemployed (compared with 24 percent of whites) in 2012 (data not shown). 
TABle 1. PERCENT OF THE LABOR FORCE (18 AND OLDER) UNDEREMPLOYED AND UNEMPLOYED BY PLACE AND DEMOGRAPHICS, 2012

\begin{tabular}{|c|c|c|c|c|c|c|c|c|c|}
\hline & \multicolumn{3}{|c|}{ ALL PLACES } & \multicolumn{3}{|c|}{ RURAL } & \multicolumn{3}{|c|}{ URBAN } \\
\hline & $\begin{array}{c}\text { Under- } \\
\text { employed }\end{array}$ & Unemployed & Combined & $\begin{array}{l}\text { Under- } \\
\text { employed }\end{array}$ & Unemployed & Combined & $\begin{array}{c}\text { Under- } \\
\text { employed }\end{array}$ & Unemployed & Combined \\
\hline TOTAL & 5.2 & 8.3 & 13.5 & 4.8 & 8.2 & 13 & 5.3 & 8.3 & 13.6 \\
\hline \multicolumn{10}{|l|}{ SEX } \\
\hline Men & 4.9 & 8.9 & 13.8 & 4.2 & 8.8 & 13.1 & 5.1 & 8.8 & 13.9 \\
\hline Women & $5.5^{*}$ & $7.7^{*}$ & $13.2^{*}$ & $5.4^{*}$ & $7.6^{*}$ & 12.9 & $5.5^{*}$ & $7.7^{*}$ & $13.2^{*}$ \\
\hline \multicolumn{10}{|l|}{ RACE } \\
\hline White & 4.2 & 6.8 & 11 & 4.1 & 7.3 & 11.4 & 4.2 & 6.7 & 10.9 \\
\hline Black & $6.3^{*}$ & $14.4^{*}$ & $20.7^{*}$ & $6.6^{*}$ & $15.2^{*}$ & $21.8^{*}$ & $6.3^{*}$ & $14.3^{*}$ & $20.6^{*}$ \\
\hline Hispanic & $8.8^{*}$ & $10.5^{*}$ & $19.3^{*}$ & $8.6^{*}$ & 9.5 & $18.1^{*}$ & $8.8^{*}$ & $10.5^{*}$ & $19.3^{*}$ \\
\hline \multicolumn{10}{|l|}{ AGE } \\
\hline 18-21 & $9.7^{*}$ & $18.8^{*}$ & $28.5^{*}$ & $8.8^{*}$ & $19.3^{*}$ & $28.1^{*}$ & $9.9^{*}$ & $18.7^{*}$ & $28.6^{*}$ \\
\hline $22-29$ & $7.2^{*}$ & $10.5^{*}$ & $17.7^{*}$ & $6.2^{*}$ & $11.4^{*}$ & $17.6^{*}$ & $7.3^{*}$ & $10.4^{*}$ & $17.7^{*}$ \\
\hline $30-39$ & $4.8^{*}$ & $7.8^{*}$ & $12.6^{*}$ & $5.3^{*}$ & $8.2^{*}$ & $13.5^{*}$ & 4.7 & $7.8^{*}$ & $12.4^{*}$ \\
\hline $40-49$ & 4.3 & $6.6^{*}$ & 10.9 & 3.8 & 6.3 & 10.1 & 4.4 & 6.7 & 11.1 \\
\hline $50-64$ & 4.2 & $6.7^{*}$ & 10.9 & 3.9 & 6.2 & 10.2 & 4.3 & 6.8 & 11.1 \\
\hline $65+$ & 3.5 & 5.7 & 9.2 & 2.4 & 5.5 & 7.9 & 3.8 & 5.8 & 9.6 \\
\hline
\end{tabular}

Notes

1. These figures are for all those in the labor force; underemployment and unemployment are mutually exclusive categories.

2. The underemployment totals in Table 1 differ from those in Table 2 because the former is a percentage of the labor force, while the latter is calculated as a percentage of employed persons only.

3. Bolded figures indicate statistically significant differences between groups across place (for example, rural men versus urban men) (logistic regression).

4. An asterisk $\left(^{*}\right)$ indicates statistically significant differences between groups within places (for example, rural men versus rural women) (logistic regression).

5. Male is reference group; White is reference group; $65+$ is reference group.

6. White and Black refer to non-Hispanic individuals, while Hispanic may be of any race.

\section{Underemployment Doubled in Rural and Urban Areas During the Great Recession}

Involuntary part-time work increased rapidly during the Great Recession, doubling between 2008 and 2009 (Figure 1). Prior to the recession, rural workers were slightly more likely than those in urban places to report involuntary part-time work. By 2009, however, rates of this form of underemployment were the same in both places, at around 6.5 percent. Rates of involuntary part-time work have declined relatively slowly since then, but remain well above their pre-recession levels, even in 2012. Indeed, the incidence of underemployment declined by just over 1 percentage-point in the last two years. By 2012, underemployment was slightly lower in rural places (a difference of about half a percentage point).

Figure 2 and Table 2 illustrate the persistent age gap in underemployment. While it existed prior to the recession, the disparity in underemployment between workers under 30 and the rest of the population widened considerably between 2008 and 2009 (Figure 2). Among 18-21-yearolds, underemployment rates were more than twice the national average in 2012 , with 13 percent of part-time
Figure 1. Percent of All EMPloyed PERSONS IN INVOLUNTARY PART-TIME WORK, 2005-2012

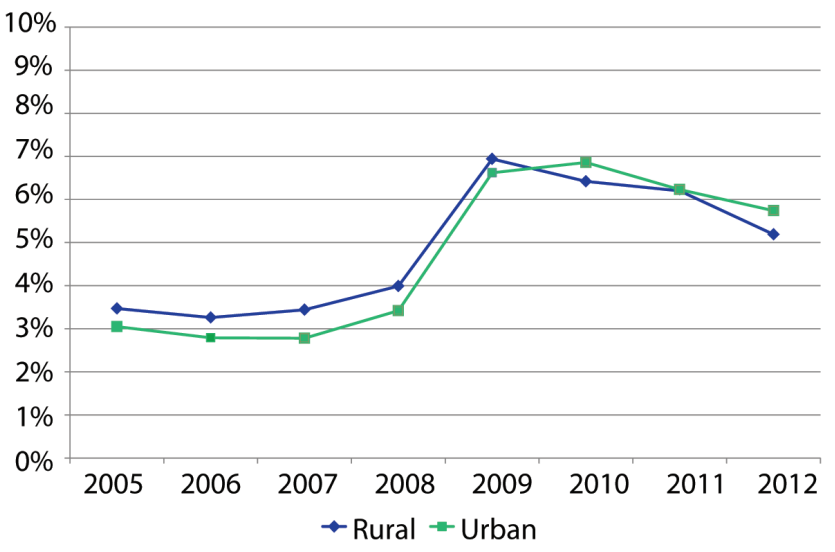

Source: Current Population Survey (March)

workers in this age group unable to find full-time work (Table 2). The rate was slightly lower for those aged 22-29, at 9 percent, although still above the national average.

These age differences suggest that workers might age out of this form of involuntary part-time employment. A cohort effect-in which underemployment differs not because of 
Figure 2. Percent of all employed persons in inVoluntary PART-TIME WORK BY AGE (ALl PLACES), 2005-2012

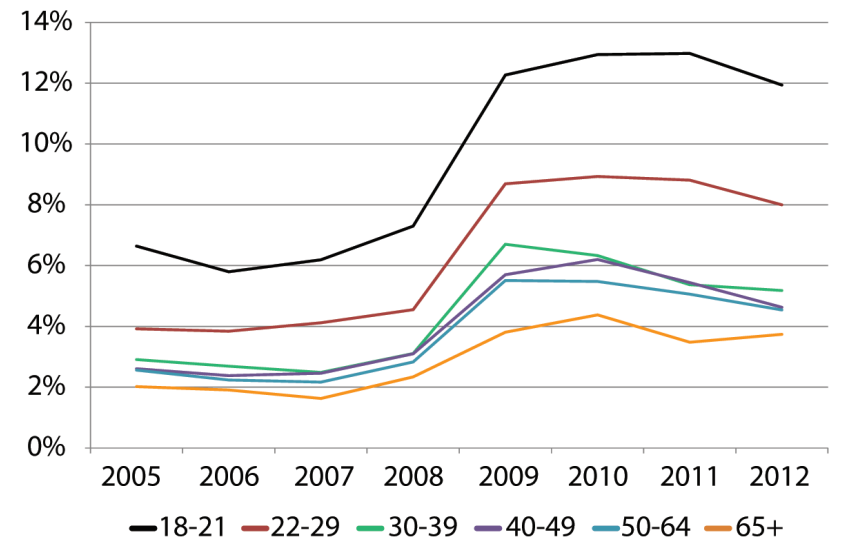

Source: Current Population Survey (March)

age but because of other factors that will follow the cohort throughout the lifecourse-is also possible given that each generation of workers faces considerably different labor market conditions.

\section{Education Matters for Involuntary Part-Time Workers}

Although the recent recession affected college-educated workers more so than past recessions, those with four-year degrees are still better off than workers without a college education (see Table 2 and Figure 3). College-educated workers experienced a slightly smaller increase in involuntary part-time work than did other workers. They were also the least likely to experience involuntary part-time work, both before and after the recession. Those with no more than a high school diploma had the highest rates of involuntary part-time employment and experienced a larger increase in this form of underemployment during the recession.

Since 2010, rates of involuntary part-time work have declined among those with no more than a high school diploma and those with two-year degrees. Among those with some college or a four-year degree, however, the rates did not decline. Although education appears to have buffered some workers, the persistent rate of underemployment among those with a four-year degree is troubling nonetheless. In contrast, where someone lives (rural or urban) appears to matter only for those with a high school diploma or less; underemployment was somewhat higher among urban workers with no more than a high school diploma than among rural workers in 2012 (9 percent versus 7 percent).
TABle 2. Percent of employed Persons UNDEREMPLOYED BY PLACE AND DEMOGRAPHICS, 2012

\begin{tabular}{l|c|c|c}
\hline & ALL PLACES & RURAL & URBAN \\
\hline TOTAL & 5.7 & $\mathbf{5 . 2}$ & $\mathbf{5 . 7}$ \\
SEX & & & \\
$\quad$ Men & 5.4 & $\mathbf{4 . 6}$ & $\mathbf{5 . 5}$ \\
$\quad$ Women & $5.9^{*}$ & $5.8^{*}$ & $6.0^{*}$ \\
RACE & & & \\
White & 4.5 & 4.4 & 4.5 \\
Black & $7.3^{*}$ & $7.7^{*}$ & $7.3^{*}$ \\
Hispanic & $9.8^{*}$ & $9.5^{*}$ & $9.8^{*}$ \\
AGE & & & \\
$\mathbf{1 8 - 2 1}$ & $11.9^{*}$ & $10.9^{*}$ & $12.2^{*}$ \\
$\mathbf{2 2 - 2 9}$ & $8.0^{*}$ & $7.0^{*}$ & $8.1^{*}$ \\
$\mathbf{3 0 - 3 9}$ & $5.2^{*}$ & $5.8^{*}$ & 5.1 \\
$\mathbf{4 0 - 4 9}$ & 4.6 & 4.1 & 4.7 \\
$\mathbf{5 0 - 6 4}$ & 4.5 & 4.2 & 4.6 \\
$\mathbf{6 5 +}$ & 3.7 & 2.5 & 4.0 \\
\hline
\end{tabular}

Notes

1. Underemployment figures are only for those whose employment status is listed as "At work" or "Has job, not at work last week."

2. Only those 18 and older are included in these calculations.

3. "Involuntary Part-Time" is calculated here as a percent of employed persons, rather than as a percent of the entire labor force.

4. "Involuntary Part-Time" refers to the percent of all employed workers who noted they are working less than 35 hours because of 1) Slack work, business conditions or 2) They could only find part-time work.

5. An asterisk $\left(^{*}\right)$ indicates statistically significant differences between groups within places (for example, rural men versus rural women) (logistic regression).

6. Bold indicates differences among groups between places (for example, rural men versus urban men) (logistic regression).

7. Male is reference group; White is reference group; $65+$ is reference group

8. White and Black refer to non-Hispanic individuals, while Hispanic may be of any race.

\section{Conclusion}

All told, 14 percent of the labor force was either underemployed or unemployed in 2012. While unemployment has declined recently, underemployment has remained persistently high in the aftermath of the Great Recession. Workers younger than 30 especially are feeling the pinch of both unemployment and underemployment, as are nonwhites. In addition, while on the decline, these rates have yet to return to their prerecession levels. Moreover, as the recession (and other economic forces) keeps older workers in the economy, openings for full-time jobs for younger workers might remain limited in the short-term.

Like the unemployed, the underemployed are a population whose skills are untapped in the present economy, and such underemployment can have dire consequences for present and future earnings, impeding the well-being of workers and their families. ${ }^{7}$ Moreover, the longer workers are underemployed, the more difficult it becomes to move 
Figure 3. PERCENT OF ALl EMPLOYED PERSONS IN INVOLUNTARY PART-TIME WORK BY EDUCATION (ALL

PLACES), 2005-2012

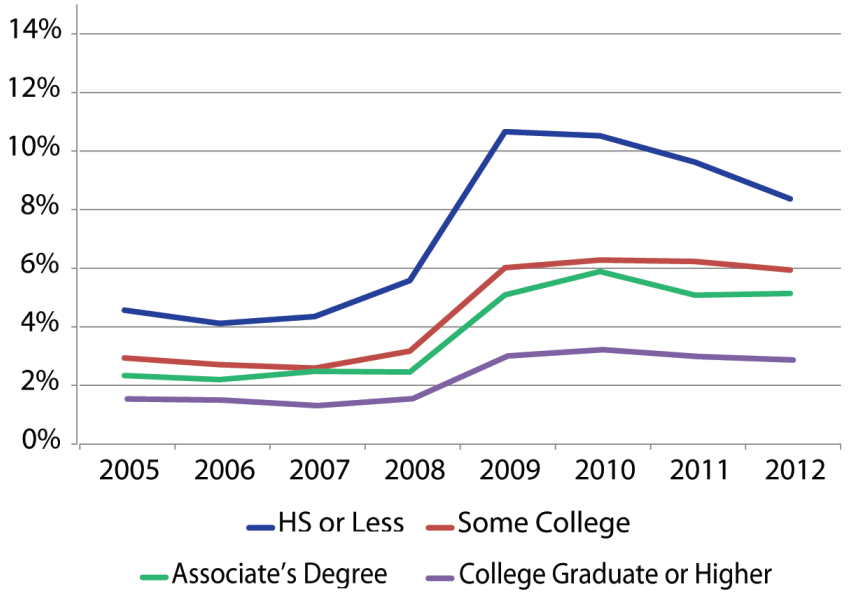

Source: Current Population Survey (March)

into better jobs as their skills (and employers' perceptions of their skills) deteriorate or remain stagnant. Further, if those entering the job market bear the financial 'scars' of the current recession for years to come, economic recovery may be that much slower and the quality of life for these workers lower. ${ }^{8}$ Policies to address unemployment and stimulate the economy should target underemployment as well as unemployment to be effective.
The relationship between education and involuntary parttime work cannot be understated (see Figure 4). Indeed, the least educated are also the most susceptible to being relegated to part-time work, thereby lowering their already lower-than-average wages. Policies that encourage the creation of positions that are full-time can lessen incidences of involuntary part-time work, but so can those that target mid-level job growth, where jobs offer higher wages and are more likely to need full-time workers. Nevertheless, underemployment is a multifaceted problem affecting some cross-sections of the population more than others, and thus requires attention from many different angles.

Figure 4. Percent of All EMPloyed PERSONS IN INVOLUNTARY PART-TIME WORK BY EDUCATION AND PLACE, 2012

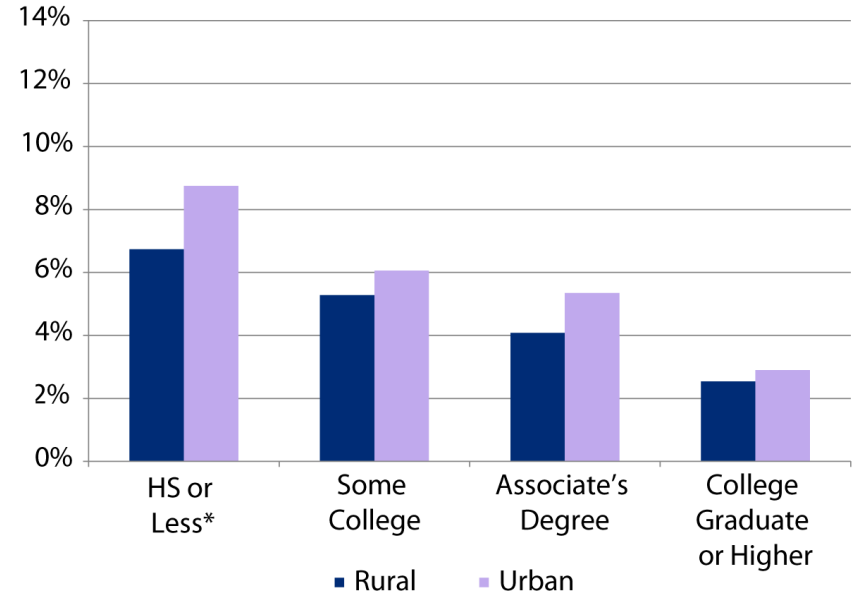

Source: Current Population Survey (March)

Note: An asterisk $\left({ }^{*}\right)$ indicates statistically significant differences $(p<.05)$. 


\section{Data and Methods}

Current Population Survey (CPS) data for this brief come from the Integrated Public Use Micro Sample for 20052012. ${ }^{9}$ CPS data generally are a barometer of the nation's economic health, and are used by the Bureau of Labor Statistics (BLS) to calculate (among other things) the official unemployment rate. Each month, the CPS surveys a representative, random sample of roughly 60,000 households. Questions include basic demographic information (for example, sex, race, age, education) and employment characteristics (including employment status, industry, and occupation).

\section{Defining Underemployment}

The BLS does not report an official underemployment rate. It is possible, however, to examine different forms of underemployment using data collected by the CPS. The measure considered here, involuntary part-time employment, is derived from data on part-time workers (those working fewer than 35 hours per week). ${ }^{10}$ All part-time workers surveyed by the CPS are asked why they worked part-time in the week prior to the survey. Those who responded either "slack work, business conditions" (for example, their employer did not have enough work for them to work full-time) or "could only find part-time" (even though they wanted full-time) are considered to be involuntary part-time workers; they are considered to be "part-time for economic reasons" according to the BLS. ${ }^{11}$ All differences discussed in this brief are statistically significant at the $p<$ 0.05 level. Data are weighted based on age, sex, and race.

\section{E N D N O T E S}

1. National Bureau of Economic Research, "U.S. Business Cycle Expansions and Contractions" (Cambridge, MA: NBER, 2010), available at: www.nber.org/cycles.html.

2. Bureau of Labor Statistics, 2012 (September), Economic News Release, "Employment Situation Summary," available at http://www.bls.gov/news.release/empsit.nr0.htm.

3. Andrew Sum and Ishwar Khatiwada, “The Nation's Underemployed in the 'Great Recession' of 2007-2009,' Monthly Labor Review, vol. 133, no. 11 (2010), available at www. bls.gov/opub/mlr/2010/11/artlexc.htm; Paul Taylor, Rich Morin, and Wendy Wang, "Most 'Re-Employed' Workers Say They're Overqualified for Their New Job" (Washington, DC: Pew Research Center, 2010), available at http://pewresearch. org/pubs/1718/re-employed-workers-recession-satisfactionjob-qualification.

4. Authors Sum and Khatiwada in "The Nation's Underemployed" analyzed involuntary part-time employment (which they referred to as underemployment) as a "percent of the employed" and "percent of total civilian employment." In addition, they calculated involuntary part-time work as "a percentage of total employment" in "Involuntary Part-Time Work on the Rise," Issues in Labor Statistics (December 2008), available at www.bls.gov/opub/ils/pdf/opbils71.pdf.

5. Some of these workers are likely to be in college, but this does not preclude them from seeking (and being unable to find) work, particularly if they are only in school part-time. In the official unemployment rate, individuals (including those in college) are only counted as unemployed if they were currently seeking but were unable to find work at the time they were surveyed. Likewise, college students, like others, are only counted as "underemployed" if they could not obtain the full-time work they were seeking at the time of the survey.

6. Authors Sum and Khatiwada also documented this increase, though their analysis did not consider rural/urban differences in involuntary part-time work.

7. Abigail Wozniak, "Are College Graduates More Responsive to Distant Labor Market Opportunities?" Journal of Human Resources, 45(4), 2010. See also Susan Guibert, "Research shows workers who begin careers during recession suffer long-term, negative effects on earnings," Notre Dame News, ND NEWSWIRE: 2010, available at http:// newsinfo.nd.edu/news/16974/.

8. Research shows that individuals who enter labor markets during times of economic decline have lower wages for many years than they would have otherwise (see citation for Wozniak, "Are College Graduates More Responsive," above). Georgetown labor economist Harry Holzer also notes that children who grow up in impoverished households also experience "wage scarring" (that is, lower incomes) as adults. 
See Holzer, "Penny Wise, Pound Foolish: Why Tackling Child Poverty During the Great Recession Makes Economic Sense" (New York: Center for American Progress, 2010), available at www.americanprogress.org/issues/2010/09/pdf/ hit_childpoverty.pdf.

9. Miriam King et al., Integrated Public Use Microdata Series, Current Population Survey: Version 3.0 [Machine-readable database] (Minneapolis: University of Minnesota, 2010).

10. Those who are involuntarily employed part-time are included in the U-6 unemployment measure, which combines the official unemployment rate with rates of involuntary part-time work and those who have given up looking for work. The U-6 measure is sometimes called the "underutilization" rate.

11. Bureau of Labor Statistics, Table A-15, "Alternative Measures of Labor Utilization” (Washington, DC: BLS, 2012), available at http://bls.gov/news.release/empsit.t15.htm. See also Bureau of Labor Statistics, "The Unemployment Rate and Beyond: Alternative Measures of Labor Underutilization" (Washington, DC: BLS, 2008), available at www.bls. gov/opub/ils/pdf/opbils67.pdf.

\section{ABOUT THE AUTHOR}

Justin R. Young is a doctoral student in sociology at the University of New Hampshire and a research assistant at the Carsey Institute (jrobertyoung@gmail.com).

\section{A C K N O W L E D G M E N T S}

The author thanks Jessica Bean, Marybeth Mattingly, Laurel Lloyd, Amy Sterndale, Curt Grimm, Rebecca Glauber, Bruce Mallory, and Barbara Ray for their comments and guidance on previous drafts, as well as the anonymous reviewers for their helpful suggestions.

\section{A UNIVERSITY - of NEW HAMPSHIRE}

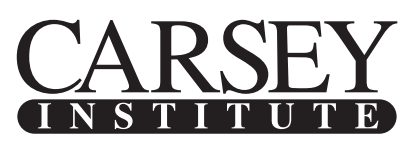

Building knowledge for families and communities

The Carsey Institute conducts policy research on vulnerable children, youth, and families and on sustainable community development. We give policy makers and practitioners timely, independent resources to effect change in their communities.

This work was supported by the Annie E. Casey Foundation, the W. K. Kellogg Foundation, and anonymous donors.

Huddleston Hall

73 Main Street

Durham, NH 03824

(603) $862-2821$

www.carseyinstitute.unh.edu 